\author{
Samanta Busiło \\ Uniwersytet Warszawski, \\ Przykarpacki Uniwersytet Narodowy im. Wasyla Stefanyka, \\ Iwano-Frankiwsk (Ukraina) \\ e-mail: se.busilo@uw.edu.pl \\ ORCID: 0000-0003-3606-8894
}

\title{
GATUNKI NAUKOWE I DYDAKTYCZNE W EDUKACJI POLONISTYCZNEJ NA UKRAINIE
}

\author{
Otwartość - czyż nie jest czymś najbardziej pustym ze wszystkiego? \\ [M. Heidegger, Przyczynki do filozofii]
}

Na początku XXI wieku, w czasie renesansu mobilności akademickiej i przemian w sposobie uprawiania nauk, a także modelu edukacji, uwarunkowanych po części cyfryzacją komunikacji, po części rewizją przekonania o linearnym rozwoju nauk, interdyscyplinarnością nauk, pluralizmem metod i podejść, mnogością i wieloznacznością terminologii, zagadnienie kompetencji językowej jest coraz częściej podejmowane na gruncie polskiej dydaktyki w kontekście uczenia języka polskiego jako obcego w odmianie akademickiej ogólnej ${ }^{1}$ [Zarzycka 2017; Busiło 2019; Jasińska 2019; 2020].

1 Termin język polski do celów akademickich (JPA) w odmianie ogólnej akademickiej i odmianie akademickiej specjalistycznej wprowadziła do polskiej glottodydaktyki Grażyna Zarzycka [Zarzycka 2017], adaptując angielskie terminy English for Academic Purpose, English for General Academic Purpose, English for Specific Academic Purpose za R. Johns [Johns 1997]. Rozwój kompetencji w zakresie języka edukacji, a szczególnie języka do celów akademickich, jest przedmiotem zainteresowania glottodydaktyki od poczatku lat 70. XX wieku [Hutchison, Waters 1987; Widdowson 1988; Swales 1995; Johns 1997; Hyland 2008; Krashen 2011; Swales, Feak 2012]. W Polsce, ze względu na długa tradycję uczenia języka polskiego studentów cudzoziemskich oraz Polaków ze Wschodu, rozwijała się dydaktyka języka polskiego jako obcego/odziedziczonego, powstawały liczne podręczniki na różne poziomy biegłości językowej w odmianie ogólnej i specjalistycznej, poddawano refleksji glottodydaktycznej zagadnienia programów i metod nauczania, testowania i certyfikacji, kompetencji językowych, w tym komunikacyjnych, lingwistycznych, socjokulturowych, realioznawczych, miejsca kultury i literatury w nauczaniu języka polskiego. Pomimo praktyk w kształceniu cudzoziemców termin JPA do 2017 roku nie funkcjonował w dyskursie glottodydaktycznym. Nie istnieje program do nauczania języka polskiego do celów akademickich ani katalog treści czy inwentarz leksykalny. Szerzej na ten temat: [Busiło 2019]. 
Dla młodego adepta nauk humanistycznych biegłość językowa jest oczywistym warunkiem szeroko rozumianego sukcesu edukacyjnego. To właśnie kompetencja językowa wpływa w znacznej mierze nie tylko na przekaz wiedzy czy nabywanie umiejętności, a tym samym na możliwość zdobywania wykształcenia i rozwoju zawodowego, ale także na zakres uczestnictwa we wspólnocie akademickiej. Dlatego rozwój kompetencji w zakresie języka edukacji powinien stanowić przedmiot badań glottodydaktycznych $z$ myślą o wyposażeniu uczelni w konkretne rozwiąania dydaktyczne.

Biorąc pod uwagę fakt, że efektywność procesu dydaktycznego wzrasta dzięki jego indywidualizacji, uwzględniając zjawisko interkomprehensji i interferencji językowych, w poniższym artykule poddano analizie porównawczej zagadnienie kompetencji akademickich związanych $z$ odbiorem i tworzeniem gatunków naukowych i dydaktycznych na gruncie edukacji polonistycznej na Ukrainie w kontekście podejmowania studiów w języku polskim w Polsce. W pierwszej części przedstawiono wykładniki stylu naukowego oraz katalog gatunków naukowych i dydaktycznych, $z$ którymi ma kontakt student $\mathrm{w}$ Polsce i na Ukrainie. W drugiej części skoncentrowano się na kompetencjach związanych $z$ redakcją tekstów naukowo-dydaktycznych, niezbędną do podjęcia studiów w Polsce ze wskazaniem cech gatunkowych, w tym struktur językowych, które moga być przyczyną interferencji językowych i powodem incydentów krytycznych w komunikacji akademickiej. Artykuł jest wyrazem doświadczeń gromadzonych przez autorkę artykułu w latach 2017-2021 podczas prowadzenia zajęć ze stylistyki języka polskiego, metodyki nauczania języka polskiego jako obcego na Przykarpackim Uniwersytecie Narodowym w Iwano-Frankiwsku. W opracowaniu wykorzystano również, zebrane w trakcie tych zajęć, a także opieki nad pracami dyplomowymi, teksty o charakterze naukowo-dydaktycznym autorstwa studentów.

\section{SPECYFIKA UCZENIA JEZZYKA UCZESTNIKÓW DYSKURSU NAUKOWEGO}

Analizując specyfikę uczenia się języka do celów akademickich, na początku warto przypomnieć poznawczy aspekt funkcji języka, który jest narzędziem kumulacji wiedzy, opisu świata i tworzenia koncepcji naukowych. W czasach relatywizmu poznawczego, pluralizmu metodologii i wielości paradygmatów naukowych poszczególnych dyscyplin, jak zgodnie twierdzą badacze współczesnego języka nauki, staje się on niejednorodny, a wielokrotnie niejasny [Chojecki 1997; Gajda 1996; 1999; Pelc 2000; Dubisz 2015]. Ponadto, jak słusznie zauważa Stanisław Gajda,

w Polsce od lat 80. zaznacza się - przede wszystkim w humanistyce - słabnięcie pozycji języka scjentyficznego. Poszerza swój zakres występowania język niescjentyficzny - stary, kontynuujący tradycje hermeneutyczne, oraz nowy, nawiązujaccy do 
nich i odwołujący się do różnych nurtów postmodernizmu, nie stroniący od metafor i ludyczności [Gajda 2001, 315].

Oznacza to, że w procesie nauki języka polskiego do celów akademickich należy przygotować (przyszłych) studentów w szczególny sposób do krytycznego myślenia, precyzji definiowania, analizy i tworzenia siatki pojęć, a także wykształcić w nich świadomość wieloznaczności terminów i różnorodności paradygmatów, modeli opisów (w wypadku nauk humanistycznych będzie to np. szkoła strukturalistyczna warszawsko-lwowska lub hermeneutystyczno-postmodernistyczna). Biegłych uczestników dyskursu naukowo-dydaktycznego należy uczyć również dyscypliny myślenia i poruszania się w zamkniętym paradygmacie danej dyscypliny, subdyscypliny, a także precyzji językowej z uwzględnieniem wykładników stylu naukowo-dydaktycznego i cech gatunkowych poszczególnych form wypowiedzi pisemnej czy ustnej.

W edukacji akademickiej umiejętność czytania i analizy tekstów, redakcji prac dyplomowych, artykułów naukowych, abstraktów, opracowywania prezentacji, przygotowywania i wygłaszania referatów, opracowywania bibliografii czy brania udziału w dyskusji wydaje się szczególnie ważna, ponieważ są to podstawowe narzędzia ewaluacji procesu dydaktycznego młodego adepta, jak również uczestnictwa w dyskursie naukowym dojrzałego i samodzielnego naukowca. $Z$ myślą o rodzimych użytkownikach języka powstaja poradniki pisania prac licencjackich, magisterskich [Szkutnik 2005; Sydor 2014]. Jeśli chodzi o pomoce dydaktyczne do nauki języka akademickiego w odmianie ogólnej dla cudzoziemców, można wymienić podręcznik A. Kugiel-Abuhasny Studiologia [Kugiel-Abuhasna 2019], zawierajaccy przede wszystkim ćwiczenia rozwijające zasób leksykalny, ale także sprawność rozumienia tekstów i poprawność gramatyczna.. W kształceniu kompetencji pisania dłuższych tekstów można wykorzystać podręczniki skoncentrowane na umiejętności redagowania form pisemnych, w tym tekstów użytkowych [Lipińska, Dabska 2016; Ruszer 2013]. Jednak dyskursywna wspólnota akademicka wykorzystuje gatunki wypowiedzi nieobecne w podręcznikach do nauczania języka polskiego dla cudzoziemców, które należy uwzględnić w procesie edukacji polonistycznej nowicjusza dyskursu naukowo-dydaktycznego, stosując zasady metodyki nauczania języków obcych.

Biorac pod uwage kanały komunikacji w dyskursie naukowym, a także metody prowadzenia badań i przechowywania danych, czy też prezentacji swoich osiagnięć naukowych, nie sposób nie podkreślić znaczenia szeroko rozumianych kompetencji informatycznych, zarówno w komunikacji ustnej, jak i pisemnej, począwszy od praktycznego wymiaru posługiwania się nowoczesną technologia, wyszukiwania informacji, obsługi programów do edycji tekstów, arkuszy kalkulacyjnych, zarówno w ich wymiarze technicznym, jak i pragmatycznym, zwiąanym 
z praktyką edytorską, redakcyjną, korektą tekstów, śledzeniem zmian w tekście w trybie recenzji itp.

\section{EDUKACJA AKADEMICKA W POLSCE I NA UKRAINIE}

Kolejna istotna kwestia, która należy wziąć pod uwagę w kształceniu językowym do celów akademickich studentów z Ukrainy, sa podobieństwa i różnice systemów edukacji, praktyk edukacyjnych, a także tradycji dyskursu naukowo-dydaktycznego w Polsce i na Ukrainie. Oba kraje biorą udział w procesie ujednolicania standardów edukacyjnych w Europie, przystapiły do procesu bolońskiego i prowadzą politykę umiędzynaradawiania uczelni. Warto jednak zaznaczyć, że na Ukrainie studia zaczyna się w wieku lat 17, w Polsce - 18. Absolwenci ukraińskich szkół średnich, którzy decyduja się na kontynuację edukacji w Polsce, są o rok młodsi od swoich kolegów, w ocenie nauczycieli akademickich często mniej samodzielni, niedostatecznie przygotowani do podjeccia aktywności akademickich [Busiło 2019]. ${ }^{2}$ Oczywiście, różnice w edukacji dotycza programów nauczania, treści, jak również metod. Inny jest zakres wiedzy ogólnej, kontekst kulturowo-historyczny. W wypadku studentów, którzy uzyskali stopień bakałarza na Ukrainie (przyznawany po 4-5 latach polonistycznych studiów I stopnia) i kontynuuja naukę w Polsce nie można zakładać, że opanowali oni umiejętność redagowania prac dyplomowych oraz pozostałych gatunków akademickich w zakresie wymaganym w Polsce. ${ }^{3}$

${ }^{2} \mathrm{~W}$ badaniu oceny kompetencji językowej studentów $z$ Ukrainy, przeprowadzonym przez autorkę w środowisku lektorów i wykładowców pracujących ze studentami cudzoziemskimi w Polsce, średnia ocen kompetencji akademickich w skali od 1 do 5 [1: bardzo słabo, 5: bardzo dobrze] wyniosła 2,7; odpowiednio: słuchanie wykładu $(3,2)$, udział w dyskusji $(3,3)$, notowanie $(1,8)$, przygotowanie prezentacji $(3,27)$, samodzielna analiza tekstu naukowego $(2,2)$, streszczenie tekstu $(2,5)$, wnioskowanie $(2,6)$, definiowanie, wskazywanie relacji i zależności $(2,7)$, redakcja artykułów naukowych $(1,6)$, opracowywanie i wygłaszanie referatu $(2,8)$, prowadzenie badań naukowych $(2,0)$, znajomość etykiety akademickiej $(3,2)$, samodzielność komunikacyjna w strukturach administracyjnych na uczelni $(3,6)$. Wśród najpowszechniejszych deficytów językowych w stopniu opanowania polszczyzny przez studentów $z$ Ukrainy wymieniono niedostatki w zakresie kompetencji socjolingwistycznych, lingwistycznych w obszarze kompetencji leksykalnej (terminologia specjalistyczna), umiejętności redagowania tekstów naukowych i dydaktycznych. Średnia ocen kompetencji kulturowych, socjokulturowych i realioznawczych wyniosła 3,0 w skali od 1 do 5; por. [Busiło 2019].

3 Analiza stanu edukacji polonistycznej na poziomie ukraińskich szkół średnich (odpowiadajacych polskiemu etapowi edukacji podstawowej i średniej), a także nauki języka polskiego jako obcego / odziedziczonego, zajmował się m.in. Jerzy Kowalewski [Kowalewski 2017], którego obszar badawczy praktycznie nie objął uczelni wyższych. Natomiast metodyką nauczania języka polskiego jako obcego w odmianie ogólnej na Ukrainie zajmowała się Ałła Krawczuk [Кравчук, 
Pomimo że metody opisane w polskich i ukraińskich podręcznikach poświęconych dydaktyce nauczania na wyższych uczelniach i formy aktywności, w tym gatunki dydaktyczne ustne i pisemne, sa podobne: wykład, ćwiczenia, laboratorium, seminarium, dyskusja, studium przypadku, to jednak nie sa identyczne, w metodykach ukraińskich nie znajdziemy takich form aktywności i zajęć jak debata oksfordzka czy konwersatorium [por. Jaroszewska, Ekiert-Oldroyd (red.) 2002; Каплінський 2015; Козмова 2014]. Z drugiej strony, proces implementacji postulowanych zasad aktywizacji, uczenia refleksyjnego i krytycznego myślenia, priorytetu umiejętności nad wiedza deklaratywna, oceniania kształtującego zaczął się na Ukrainie później niż w Polsce i w praktyce jest różnie realizowany. Jako skrajny przykład można podać zadanie zaliczające przedmiot, polegające na odręcznym przepisaniu całego podręcznika, które dostali studenci polonistyki jednego $z$ uniwersytetów. Wszystkie formy akademickiej aktywności pisemnej i ustnej powinny się znaleźć w katalogu treści programów nauczania języka polskiego do celów akademickich, szczególnie te niewystępujące, mało popularne lub inaczej realizowane na Ukrainie.

Warto również zwrócić uwagę na relacje nowicjusz - ekspert, student - wykładowca, które powoli się zmieniają w podobnym kierunku w Polsce i na Ukrainie, zarówno w obszarze oczekiwań ról stawianych wykładowcy, jak i studentowi. Postawy typowe dla hierarchicznych społeczeństw, opartych na niepodważalnym autorytecie, oczekujących od uczniów niemalże automatycznej absorpcji wiedzy, powoli ustępuja miejsca refleksyjnemu uczeniu się i konfrontowaniu wiedzy zdobywanej z już nabyta, chociaż - jak pokazuje indeks wymiarów kultury Geerta Hofstede [Hofstede, Hefstede 2007] - Ukraina reprezentuje wysoki stopień dystansu władzy (92), Polska odpowiednio niższy (68). Pod względem indywidualizmu Polska wiedzie prym (60) w porównaniu z Ukraina (25), ${ }^{4}$ co w praktyce określa charakter edukacji, który też należy uwzględnić w procesie dydaktycznym ukierunkowanym na rozwój kompetencji akademickich.

\section{GATUNKI NAUKOWE I DYDAKTYCZNE W PERSPEKTYWIE GLOTTODYDAKTYCZNEJ}

Analizując zagadnienie kształcenia kompetencji językowych w obszarze odbioru i redakcji gatunków, na wstępie należy zwrócić uwagę na funkcjonujacy w glottodydaktyce polonistycznej termin forma wypowie$d z i$, który znajdziemy m.in. w programach nauczania [Programy... 2016]

Ковалевський 2017]. Monografie obojga autorów moga jednak posłużyć za istotny kontekst organizacji procesu dydaktycznego na uczelniach wyższych.

4 Por. https://www.hofstede-insights.com/product/compare-countries/ [dostęp: 10.04.2021]. 
i de facto oznacza on pojęcie gatunku rozumianego w językoznawstwie jako „kulturowo i historycznie ukształtowany oraz ujęty w społeczne konwencje sposób językowego komunikowania się; wzorzec organizacji tekstu" [Gajda 2001a, 255]. W niniejszym artykule przyjęto jednak terminologię językoznawcza, odwołanie się bowiem do teorii gatunku - a tym samym pojęcia wzorca gatunkowego, obejmujaccego kategorie formalnojęzykowe, kognitywne oraz pragmatyczne, wykładniki stylu naukowego reprezentowanego przez poszczególne gatunki - stwarza możliwość przełożenia wiedzy językoznawczej na praktykę dydaktyczną i refleksję glottodydaktyczna. Podobne podejście proponuje Anna Dunin-Dudkowska, odwołując się do czterech aspektów wzorca gatunkowego zaproponowanych przez M. Wojtak [Wojtak 2013]: strukturalnego, pragmatycznego, kognitywnego i stylistycznego, podkreślając jednocześnie, jak ważne jest wykorzystanie zdobyczy genologii w praktyce dydaktycznej [Dunin-Dudkowska 2018, 116]. ${ }^{5}$

Przedstawienie cech prototypowych oraz cech fakultatywnych gatunku $z$ uwzględnieniem jego kompozycji, struktur językowych w płaszczyźnie leksyki, frazeologii, gramatyki, ortografii i interpunkcji, uwzględniajacych realizację funkcji komunikacyjnych (informacyjnych, metatekstowych i in.), a także zasad redakcji i edycji, powinno być ważnym elementem kształcenia biegłości językowej w zakresie komunikacji akademickiej. Dlatego z myślą o planowaniu i organizacji procesu dydaktycznego istotne sa:

- określenie katalogu gatunków naukowo-dydaktycznych, z którymi ma do czynienia student,

- analiza poszczególnych gatunków ze względu na rodzaj kompetencji komunikacyjnych (recepcja, produkcja, interakcja, mediacja),

- ustalenie częstości kontaktu studenta w czasie nauki $z$ danym gatunkiem i wagi gatunku w procesie nauczania,

- określenie stopnia trudności formy i wymaganego poziomu biegłości językowej reprezentowanego przez studenta do realizacji danego gatunku,

- określenie struktur językowych, których znajomość jest niezbędna do realizacji gatunku (będących po części pochodna funkcji komunikacyjnych, po części wykładników językowych stylu),

- określenie obszaru interkomprehensji i intereferencji międzyjezzykowych, uwzględniajacc język rodzimy / pierwszy język studenta / język dotychczasowej edukacji studenta.

Wśród 64 gatunków (form wypowiedzi) wymienionych w programach nauczania języka polskiego jako obcego [Programy... 2016] tylko 8 reprezentuje po części odmianę stylu naukowego; sa to: artykuł popularnonaukowy, streszczenie, rozprawka (tekst argumentacyjny), recenzja,

$5 \mathrm{~W}$ artykule znajdziemy również szczegółowa analizę terminu formy wypowiedzi [Dunin-Dudkowska 2018, 118]. 
rozmowa, dyskusja / głos w dyskusji, wywiad, CV, list. Należy przy tym zauważyć, że niektóre $z$ nich, jak np. streszczenie, funkcjonują nie tylko w naukowym wariancie języka polskiego, ale także w odmianie ogólnej. Podręczniki do nauki języka polskiego jako obcego w zakresie form pisemnych realizuja dostępne programy nauczania. Wydaje się zatem, że opracowanie listy gatunków i spełnienie powyżej wymienionych etapów organizacji kształcenia językowego (przyszłych) studentów przyczyni się do powstania podręczników i wypełni istniejącą lukę.

Poniżej przedstawiono propozycję rejestru gatunków naukowo-dydaktycznych, $z$ uwzględnieniem ich charakteru komunikacji w glottodydaktycznym ujęciu działań językowych $z$ podziałem na gatunki, które polegaja na recepcji (rozumieniu tekstów), produkcji (tworzeniu tekstów), interakcji i mediacji. ${ }^{6}$ Uwzględniono także kanał komunikacji: ustny, pisemny, mieszany, odwołując się do klasyfikacji gatunków akademickich Johna Swalesa [Swales 2007]. Ponadto powiazano je $z$ konkretnymi etapami edukacji oraz zaproponowano poziomy biegłości językowej ( $z$ uwzględnieniem kompetencji biernej (rozumienie) i czynnej (tworzenie), na których warto dane formy wprowadzać, biorąc pod uwagę frekwencję ich występowania w komunikacji akademickiej oraz wage określona stopniem, w jakim opanowanie danej formy wpływa na osiagnięcie sukcesu edukacyjnego. Zrozumiałe jest, że pracę dyplomowa pisze się w ramach konkretnych studiów jeden raz, jednak sprawność w zakresie redakcji rozprawy licencjackiej czy magisterskiej warunkuje pomyślne ich ukończenie i uzyskanie odpowiedniego stopnia naukowego.

Jako podstawa opracowanego rejestru gatunków posłużyła klasyfikacja Stanisława Gajdy [Gajda 1982], oparta na czterech odmianach języka nauki (naukowej właściwej czy teoretycznej, dydaktycznej, praktycznej, popularno-naukowej) [Gajda 2001b], czego wyrazem jest - obok klasycznych gatunków naukowych takich jak artykuł, rozprawa czy podręcznik - równoległa obecność takich form jak egzamin, zadanie czy ćwiczenie. W wypadku niektórych gatunków hybrydowych zdecydowano się wprowadzić pododmiany - naukowa i popularnonaukowa (np. w wypadku artykułu - naukową i popularnonaukowa), ze względu na stopień trudności tekstu, co w kontekście dydaktyki języka obcego przekłada się na strategie nauczania. W tworzeniu listy gatunków wykorzystano także programy nauczania języka polskiego jako obcego [Programy... 2016] oraz program nauczania języka polskiego w odmianie akademickiej Grażyny Zarzyckiej [Zarzycka 2017]. Przy ustalaniu form aktywności ustnej i pisemnej pomocne były również wspomniane już metodyki nauczania na wyższych uczelniach [por. Jaroszewska, Ekiert-Oldroyd (red.) 2002; Каплінський 2015; Козмова 2014]. Nie uwzględniono specyfiki internetowej genologii gatunków ani podziału na gatunki synchro-

6 Por. https://www.hofstede-insights.com/product/compare-countries / [dostęp: 10.04.2021]. 
niczne i asynchroniczne ze względu na czas komunikacji oraz interakcję nadawcy i odbiorcy, chociaż z pewnościa sa to ważne parametry tekstów. Wybór gatunków był motywowany przede wszystkim ich frekwencją i waga w procesie dydaktycznym na wyższych uczelniach w Polsce. Uwzględniono przede wszystkim te gatunki, $z$ którymi ma kontakt współczesny student oraz te, które są warunkiem osiagnięcia sukcesu edukacyjnego.

\section{Zestawienie gatunków naukowo-dydaktycznych w kontekście} glottodydaktycznym (opracowanie wlasne)

\begin{tabular}{|c|c|c|c|c|c|c|c|c|c|c|c|c|c|c|c|}
\hline & & 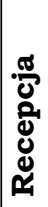 & 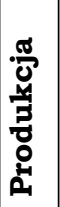 & 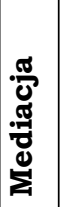 & 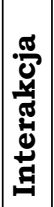 & 总 & 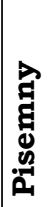 & 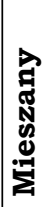 & 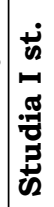 & 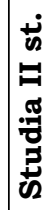 & 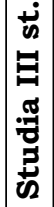 & 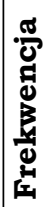 & ఝ్ర్య & 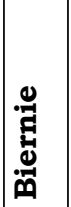 & 胥 \\
\hline 1. & Artykuł naukowy & + & + & $(+)$ & & & + & & + & + & + & + & + & B2 & $\mathrm{C} 1$ \\
\hline 2. & Artkuł popularnonaukowy & + & + & & & & + & & + & + & + & + & + & B1 & B2 \\
\hline 3. & Rozprawa & + & + & $(+)$ & & & & & + & + & & + & + & B2 & B2 \\
\hline 4. & $\begin{array}{l}\text { Praca dyplomowa } \\
\text { licencjacka (rozprawa) }\end{array}$ & + & + & $(+)$ & & & & & + & & & & + & B2 & $\mathrm{C} 1$ \\
\hline 5. & $\begin{array}{l}\text { Praca dyplomowa } \\
\text { magisterska (rozprawa) }\end{array}$ & + & + & $(+)$ & & & & & & + & & & + & B2 & $\mathrm{C} 1$ \\
\hline 6. & $\begin{array}{l}\text { Dysertacja (rozprawa } \\
\text { doktorska) }\end{array}$ & + & + & $(+)$ & & & + & & & & + & & & B2 & $\mathrm{C} 2$ \\
\hline 7. & Monografia & + & $(+)$ & $(+)$ & & & + & & + & + & + & + & + & B2 & $(\mathrm{C} 2)$ \\
\hline 8. & Referat & + & + & $(+)$ & & & & + & + & + & + & + & + & B2 & B2 \\
\hline 9. & Koreferat & + & + & $(+)$ & & & & + & + & + & + & & + & B2 & B2 \\
\hline 10. & Abstrakt (streszczenie) & + & + & + & & & + & & + & + & + & + & + & B2 & B2 \\
\hline 11. & Streszczenie & + & + & + & & $(+)$ & + & & + & + & + & + & + & B1 & B1 \\
\hline 12. & Bibliografia & + & + & $(+)$ & & & + & & + & & & + & + & B1 & B1 \\
\hline 13. & Raport & + & + & + & & & + & & + & + & + & & & B2 & $\mathrm{C} 1$ \\
\hline 14. & Encyklopedia & + & & $(+)$ & & & + & & + & + & + & + & + & B1 & $\mathrm{C} 2$ \\
\hline 15. & $\begin{array}{l}\text { Artykuł w encyklopedii } \\
\text { (hasło encyklopedyczne) }\end{array}$ & + & & $(+)$ & & & + & & + & + & + & + & + & A2 & B2 \\
\hline 16. & Słownik & + & & $(+)$ & & & + & & + & + & + & + & + & A1 & $\mathrm{B} 2$ \\
\hline 17. & Definicja słownikowa & + & & $(+)$ & & & + & & + & + & + & + & + & A1 & B2 \\
\hline 18. & Esej & + & + & + & & & + & & + & + & + & + & & B1 & B1 \\
\hline 19. & $\begin{array}{l}\text { Praca zaliczeniowa (esej } \\
\text { naukowy) }\end{array}$ & + & + & $(+)$ & & & & & + & + & + & + & + & B2 & B2 \\
\hline
\end{tabular}




\begin{tabular}{|c|c|c|c|c|c|c|c|c|c|c|c|c|c|c|c|}
\hline & & 悉 & 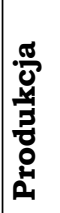 & 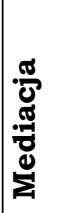 & 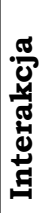 & 空 & $\begin{array}{l}\vec{Z} \\
\mathbf{Z} \\
\mathbb{0} \\
: 2 \\
\ddot{Z}\end{array}$ & 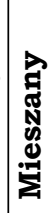 & 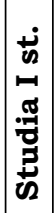 & 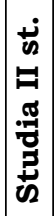 & 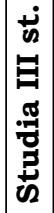 & 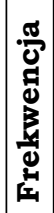 & ఝ్ర్ & 总 & 胥 \\
\hline 20. & Recenzja & + & + & + & & & + & & + & + & + & + & + & B1 & B2 \\
\hline 21. & Opinia & + & + & & & & + & & + & + & + & + & & B2 & B2 \\
\hline 22. & Sprawozdanie & + & + & & & & + & & + & + & + & + & + & B2 & B2 \\
\hline 23. & Podręcznik (akademicki) & + & + & & & & + & & + & + & + & + & + & B2 & $\mathrm{C} 2$ \\
\hline 24. & Skrypt & + & + & & & & + & & + & + & + & + & & B2 & $\mathrm{C} 2$ \\
\hline 25. & Wykład & + & $(+)$ & & & + & & + & + & + & + & + & + & B2 & $\mathrm{C} 2$ \\
\hline 26. & Odczyt & + & $(+)$ & & & & & + & + & + & + & + & & B1 & B1 \\
\hline 27. & Pogadanka & + & $(+)$ & & & + & & & + & + & + & + & & B1 & $\mathrm{C} 2$ \\
\hline 28. & Poradnik & + & & & & & + & & + & + & + & & & B1 & B1 \\
\hline 29. & Zadanie & + & & & & + & + & & + & + & + & + & + & A1 & A 1 \\
\hline 30. & Ćwiczenie & + & + & & & + & + & & + & + & + & + & + & A1 & $\mathrm{C} 1$ \\
\hline 31. & Rozmowa & + & + & + & & + & & & + & + & + & + & + & A1 & $\mathrm{C} 1$ \\
\hline 32. & Konsultacja & + & + & & & + & + & & + & + & + & & + & B1 & $\mathrm{C} 1$ \\
\hline 33. & Egzamin & + & + & & & + & + & & + & + & + & & + & B2 & $\mathrm{C} 1$ \\
\hline 34. & Dyskusja/głos w dyskusji & + & + & + & & & & & + & + & + & + & + & B1 & B2 \\
\hline 35. & Debata oksfordzka & + & + & & & & & & + & + & + & & & $\mathrm{B} 2$ & B2 \\
\hline 36. & Polemika & + & + & $(+)$ & + & + & + & & + & + & + & & + & B1 & B2 \\
\hline 37. & Panel & + & + & $(+)$ & + & + & & & + & + & + & & & B1 & B2 \\
\hline 38. & $\begin{array}{l}\text { Tekst argumentacyjny } \\
\text { (rozprawka) }\end{array}$ & + & + & + & & & + & & + & + & + & & + & B1 & B1 \\
\hline 39. & Słownik (element tekstu) & + & $(+)$ & $(+)$ & & & + & & + & + & + & & & B1 & B2 \\
\hline 40. & Indeks & + & $(+)$ & $(+)$ & & & + & & + & + & + & & & B1 & B2 \\
\hline 41. & Wykaz danych & + & $(+)$ & $(+)$ & & & + & & + & + & + & & & B2 & B2 \\
\hline 42. & Spis treści & + & + & + & & & + & & + & + & + & + & + & A1 & B1 \\
\hline 43. & Aneks & + & $(+)$ & $(+)$ & & & + & & + & + & + & & & B1 & B2 \\
\hline 44. & Przypisy & + & + & $(+)$ & & & + & & + & + & + & + & + & B1 & B2 \\
\hline 45. & Konspekt & + & $(+)$ & $(+)$ & & & + & & + & + & + & & + & B1 & B2 \\
\hline 46. & $\begin{array}{l}\text { Prezentacja } \\
\text { (multimedialna) }\end{array}$ & + & + & $(+)$ & & & & + & + & + & + & + & + & B2 & B2 \\
\hline 47. & Program zajęć & + & $(+)$ & $(+)$ & & & + & & & & + & & & B1 & B1 \\
\hline 48. & Sylabus zajęć & + & $(+)$ & $(+)$ & & & + & & & & + & + & + & B2 & $\mathrm{C} 1$ \\
\hline
\end{tabular}




\begin{tabular}{|c|c|c|c|c|c|c|c|c|c|c|c|c|c|c|c|}
\hline & & 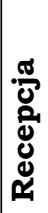 & 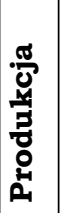 & 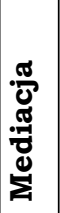 & 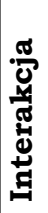 & 点 & 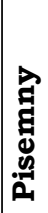 & 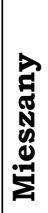 & 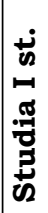 & 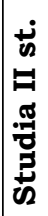 & 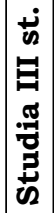 & 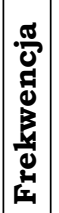 & $\mid$ & 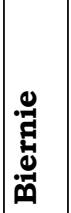 & 胥 \\
\hline 49. & Konspekt zajęć & + & $(+)$ & $(+)$ & & & + & & & & + & & & $\mathrm{B} 2$ & B2 \\
\hline 50. & Sprawozdanie (z praktyk) & + & $(+)$ & $(+)$ & & & + & & + & + & + & & & $\mathrm{B} 2$ & B2 \\
\hline 51. & Dziennik praktyk & + & $(+)$ & $(+)$ & & & + & & + & + & + & & & $\mathrm{B} 2$ & B2 \\
\hline 52. & Opis projektu badawczego & + & $(+)$ & $(+)$ & & & + & & + & + & + & & + & B2 & B2 \\
\hline 53. & CV naukowe & + & $(+)$ & $(+)$ & & & + & & + & + & + & & + & B2 & B2 \\
\hline 54. & Wywiad (naukowy) & + & $(+)$ & $(+)$ & + & & + & & + & + & + & & & B2 & B2 \\
\hline 55. & Ankieta (badawcza) & + & $(+)$ & $(+)$ & & & + & & + & + & + & & + & B2 & B2 \\
\hline 56. & Zajęcia praktyczne & + & + & $(+)$ & + & & & + & + & + & + & + & + & B2 & B2 \\
\hline 57. & Leksykon & + & + & $(+)$ & & & + & & + & + & + & & & B1 & $\mathrm{C} 1$ \\
\hline 58. & Glosariusz & + & + & $(+)$ & & & + & & + & + & + & & & B1 & $\mathrm{C} 1$ \\
\hline
\end{tabular}

Legenda: $(+)$ fakultatywnie.

W przedstawionym zestawieniu, oprócz prototypowych gatunków naukowych reprezentujacych odmianę naukowa teoretyczną i dydaktyczna, znajdują się również gatunki dydaktyczne, które są pochodną metodyki nauczania na wyższych uczelniach, aktywności podejmowanych przez studentów ${ }^{7}$ oraz organizacji procesu dydaktycznego, nieujęte w klasyfikacji Stanisława Gajdy, takie jak na przykład program zajęć, sylabus zajęć, sprawozdanie $z$ praktyk (przedmiotowych, zawodowych), dziennik praktyk itp. Umiejętność ich opracowania wymaga od studentów umiejętności posługiwania się rejestrem języka naukowego w odmianie dydaktycznej, a także znajomości cech gatunkowych.

Kolejną ważna grupa ze względu na funkcję w procesie edukacji są gatunki umożliwiające prowadzenie badań, takie jak wywiad, ankieta czy studium przypadku. Chociaż występują one również w rejestrze innych odmian języka polskiego (wywiad - odmiana publicystyczno-dziennikarska, ankieta - odmiana kancelaryjno-urzędowa), należy uczyć zasad ich redakcji w kontekście komunikacji akademickiej. Warto również zwrócić uwage na gatunki o charakterze hybrydowym, takie jak np. CV naukowe czy recenzja, streszczenie (abstrakt); maja one swoiste cechy genologiczne, a ich redakcja wymaga również znajomości struktur właściwych językowi nauki.

7 Kompletny i inspirujacy katalog aktywności akademickich opracowała G. Zarzycka, por. [Zarzycka 2017]. 
W procesie edukacji językowej do celów akademickich szczególną uwagę należy poświęcić umiejętności przygotowania prezentacji multimedialnej, która może być elementem zarówno wykładu, jak i referatu. Wymaga zarówno kompetencji redakcyjnych, jak i informatycznych. Ponadto wygłoszenie wykładu czy referatu ze wsparciem prezentacji multimedialnej wymaga osobnych umiejętności retorycznych i praktycznych zwiazanych $z$ komunikacja o charakterze mieszanym (wykorzystujacej kod pisany i mówiony).

Oczywiście gatunki, które funkcjonują równolegle w języku ogólnym albo odmianie popularnonaukowej, moga reprezentować odpowiednio mniejszy stopień trudności i być realizowane na wcześniejszych etapach biegłości językowej. Tak jest na przykład w wypadku streszczenia, recenzji, ankiety i wywiadu. Ze słowników korzystają osoby uczące się języka już na poziomie A1, natomiast umiejętność tworzenia słowników będących elementem pracy dyplomowej czy rezultatem projektu naukowego wymaga innego poziomu biegłości językowej, a rozumienie hasła w słowniku lub w encyklopedii i umiejętność redagowania tych haseł - jeszcze innego, odpowiednio wyższego poziomu biegłości językowej. Dlatego wartości wpisane w tabeli są optymalne i należy je dostosować do konkretnej sytuacji komunikacyjnej i dydaktycznej.

Wszystkie ujęte w rejestrze gatunki o dużej wadze są obecne w dyskursie naukowo-dydaktycznym na Ukrainie, różnią się jednak wariantami realizacji wzorca gatunkowego [Онуфрієнко 2009]. Student kontynuujący naukę w Polsce $z$ jednej strony może wykorzystać nabyte umiejętności w zakresie organizacji tekstu, znajomość struktury tekstu, a także takich wykładników stylu naukowego jak logiczność, zwięzłość, spójność, abstrakcyjność czy obiektywizm, z drugiej jednak strony jest narażony na konsekwencje transferu negatywnego. Przykłady tych konsekwencji opisano poniżej w zestawieniu częstych błędów w realizacji wzorca gatunkowego na podstawie analizy przede wszystkim prac zaliczeniowych i dyplomowych.

\section{ROZWIJANIE KOMPETENCJI W ZAKRESIE REDAGOWANIA TEKSTÓW NAUKOWYCH (Z UWZGLĘDNIENIEM POTRZEB STUDENTÓW Z UKRAINY)}

Ucząc redakcji tekstów akademickich, należy stosować te same zasady metodyki nauczania i strategie dydaktyczne w zakresie rozwijania sprawności pisania, które stosujemy w wypadku tekstów w innych odmianach jezzyka polskiego. Wykorzystujemy techniki pisania kontrolowanego, częściowo sterowanego, wolnego, a także ćwiczenia wprowadzające struktury językowe niezbędne do realizacji gatunku, ćwiczenia $z$ wykorzystaniem przykładowych tekstów (porządkowanie fragmentów tekstu, dopasowywanie elementów, streszczanie, nadawanie tytułów, od- 
powiadanie na pytania, wyszukiwanie informacji, itp.). ${ }^{8}$ Możemy zastosować metodę indukcji lub dedukcji, zaczaćc od prezentacji reguły danej formy, pokazać przykład, zainicjować próby redakcyjne, dokonać korekty, oceny, omówić realizację i jeśli zachodzi taka potrzeba, zadbać o ponowna redakcję i poprawę. Model ten sprawdzi się w wypadku krótszych objętościowo wypowiedzi. W pracy magisterskiej czy dyplomowej należy dostosować ten schemat do długiego procesu powstawania pracy - pokazać wzorzec, nauczyć struktury, zasad redakcji poszczególnych segmentów, zadbać o opanowanie środków językowych niezbędnych do realizacji danej formy. Warto przy tym realizować postulat integracji sprawności, łączenia pisania $z$ mówieniem, słuchaniem i czytaniem. Warto oczywiście zadbać o to, by tematyka materiałów i stopień trudności odpowiadał profilowi edukacyjnemu studentów. W wypadku studentów $z$ Ukrainy należy zwrócić szczególną uwagę na potencjalne incydenty krytyczne w komunikacji wywołane przez zjawisko transferu językowego. Powyższe zasady można przedstawić w kilku krokach:

1. Analiza wzorca, praca $z$ wzorcem $z$ wykorzystaniem technik rozwijających rozumienie tekstu (fakultatywnie: struktury języka, styl, poprawność językowa);

2. Przedstawienie / odkrycie struktury (metoda indukcji lub dedukcji);

3. Wprowadzenie i utrwalenie struktur językowych (leksykalnych i gramatycznych);

4. Zwrócenie uwagi na cechy gatunkowe, aspekt stylistyczny, aspekt strukturalny, aspekt pragmatyczny, aspekt kognitywny;

5. Zwrócenie uwagi na zjawisko interferencji i interkomprehensji;

6. Wykorzystanie strategii mediacji, m.in. techniki przekładu i streszczenia;

7. Wykorzystanie techniki poprawy tekstu, redakcji, edycji;

8. Ćwiczenia w pisaniu kontrolowanym, sterowanym i samodzielnym.

W procesie rozwoju kompetencji redakcji tekstów naukowych warto skoncentrować się na środkach językowych, będących prototypowymi wykładnikami stylu naukowego, wyrażającymi:

- abstrakcyjny charakter tekstów naukowych (formacje słowotwórcze, zakończone na -ość, -anie, -enie; gniazda słowotwórcze typowe dla terminologii, elementy kodów nienaturalnych, symbole i skróty, złożone struktury składniowe);

- zasadę jasności, zwięzłości i logiczności (spójniki wskazujące na relacje logiczne oraz wskaźniki zespolenia i elementy metatekstowe budujące spójność, porządek i hierarchię tekstu, a także ukazujące strukturę i segmentację tekstu);

- obiektywizm tekstów (zdania bezosobowe, konstrukcje modalne).

8 Więcej o zasadach rozwijania sprawności pisania i pisowni zob. [Seretny, Lipińska 2005, 45-74, 227-252]. 
Odwołując się do doświadczeń pracy ze studentami z Ukrainy, analizując ich teksty naukowo-dydaktyczne, w tym referaty, prezentacje, prace zaliczeniowe, prace dyplomowe, a także opierając się na publikacjach poświęconych błędom językowym osób słowiańskojęzycznych $^{9}$ [Izdebska-Długosz 2021b; Dunin-Dudkowska, Maliszewski 2018; Maliszewski 2019; Krawczuk 2006], przedstawiam poniżej przykłady najczęstszych błędów - spowodowanych w większości interferencja językowa - zwiazanych $z$ realizacja wzorca gatunkowego na poziomie struktury tekstu, stylu, leksyki, gramatyki, ortografii i interpunkcji. Właśnie tym zagadnieniom warto poświęcić więcej uwagi w procesie dydaktycznym. ${ }^{10} \mathrm{~W}$ wypadku słownictwa koncentruję się na leksyce typowej dla akademickiej odmiany języka polskiego, w wypadku gramatyki - na formach będących wykładnikami języka naukowego (formach bezosobowych, składni zdań złożonych, itp.). W większości analizowanych form w strukturze powinny się znaleźć segmenty: wstęp, zakończenie, bibliografia, w wypadku prac dyplomowych dodatkowo powinny wystąpić: karta tytułowa, wstęp, spis treści, wnioski, fakultatywnie aneksy, indeksy, słowa klucze. We wszystkich tych formach (poza prezentacja) tekst powinien być podzielony na akapity, paragrafy i rozdziały (prace dyplomowe).

\section{CZESTO SPOTYKANE BEĘDY W PRACACH STUDENTÓW Z UKRAINY ZWIAZANE Z REALIZACJA WZORCA GATUNKOWEGO (NA PRZYKIADZIE PRAC DYPLOMOWYCH, REFERATÓW I PREZENTACJI) ${ }^{11}$}

a) Błędy stylu, kompozycji i układu tekstu:

- stosowanie ukraińskiego modelu strony tytułowej pracy,

- podawanie danych autora pracy w formie celownika, zamiast mianownika, np.:

9 Piszę o „studentach z Ukrainy” i „osobach słowiańskojęzycznych”, dlatego że na Ukrainie dla części osób pierwszym językiem komunikacji jest język ukraiński, dla części - język rosyjski, część mieszkańców jest dwujęzyczna. Badania Pawła Lewczuka wykazały, że większość studentów z Ukrainy w Polsce jest prymarnie rosyjskojęzyczna [Levchuk 2020, 116].

10 Ustalajac obszar interferencji międzyjęzykowych polsko-ukraińskich, wykorzystano m.in. studia kontrastywne poświęcone językowi polskiemu i ukraińskiemu [Kononenko 2012; Śpiwak 2003], a także słownik polsko-ukraińskich homonimów [Кононенко, Співак 2008] oraz słownik tematyczny polsko-ukraiński [Kononenko, Mytnik, Wasiak 2010]. Językowe błędy Ukraińców spowodowane interferencją analizowała również Ałła Krawczuk [m.in. Krawczuk 2006; Кравчук 2011, 354-367].

11 Przykłady pochodza $z$ korpusu kilkudziesięciu prac studenckich zebranych przez autorkę w latach 2018-2019 w dwóch ośrodkach akademickich - na Uniwersytecie Warszawskim oraz Przykarpackim Uniwersytecie Narodowym. Do analizy korpusu wykorzystano program AntConc. 
*Praca studentki III roku polonistyki Oksany Lewczuk,

- podawanie inicjałów imion i imion po nazwisku autora, opiekuna naukowego itp.;

- stosowanie równoważników zdań jako samodzielnych wypowiedzeń w tekstach oraz konstrukcji $z$ wykorzystaniem bezokolicznika albo struktur nominalnych o charakterze tytułu jako fragmentu akapitu, np.:

*Dla tłumaczy, nauczycieli, uczniów, wydawców (fragment abstraktu);

${ }^{*}$ Cel $i$ metodologia badań (fragment wstępu do pracy, początek akapitu);

- powtórzenia, skróty myślowe typowe dla odmiany mówionej języka, błędy logiczne, niestosowne metafory, nadmiar struktur dopełniaczowych, zbędne negacje, nadużywanie zaimków wskazujących (błędy o charakterze uniwersalnym), np.:

*We wnioskach podsumowano wykonana prace;

*Wśród językoznawców nie ma jednomyślności co do określenia centralnej jednostki przedmiotu (zamiast: przedmiotu badań frazeologii jako dziedziny języ koznawstwa), jego natury, znaczenia i tak dalej; błąd leksykalny i błąd stylistyczny;

*Praca może być wykorzystana do prowadzenia zajęć z literatury obcej XIX wieku;

*Na podstawie tego G. Sienkiewicz nazwat B. Prusa kolosalnym, wszechogarniajacym okiem Polski (zamiast: na podstawie tego / opisanego / powyższego wydarzenia);

- niestosowność i niejednorodność stylistyczna, fragmenty zbyt poetyckie lub potoczne, nacechowane emocjonalnie, noszące znamiona patosu, o charakterze publicystyczno-dziennikarskim, pełniace funkcje agitacyjne, nie informacyjne, np.:

* Przecież dla tego, żeby dobrze mówić i pisać, nie wystarczy znać tylko reguły języka literackiego, określone $w$ gramatyce $i$ ortografii, trzeba także nauczyć sie leksyki $i$ i frazeologii, tak zwane skarby językowe, nauczyć się wykorzystywać ich $w$ swojej praktyce językowej;

- odstępstwa od normy w edycji tekstu, organizacji graficznej, m.in. stosowanie czcionki 14 p. do tekstu podstawowego, interlinii 1 (pod wpływem standardów edycji w tekstach ukraińskich), nadmiar tekstu na slajdach, nieprawidłowe przenoszenie wyrazów, dzielenie wersów, brak wyjustowania tekstu (błędy o charakterze uniwersalnym), preferowanie wzorców typowych dla ukraińskich tekstów naukowych odwoływania się do bibliografii, np.:

*[42] (zamiast: [Dubisz 2012] czy zastosowanie przypisu dolnego);

- brak spójności tekstu, zakłócenia w porządku pracy, nieprawidłowa segmentacja tekstu, nieprawidłowa konstrukcja akapitu, brak akapitów, nieprawidłowa objętość poszczególnych segmen- 
tów, zbyt obszerny wstęp, brak wniosków (błędy typowe również dla rodzimych użytkowników języka);

- lapidarność, pustosłowie oraz inne błędy związane $z$ nieznajomościa wzorca gatunkowego, np. podawanie dwudziestu nazwisk po przecinku, bez komentarza w części pracy omawiającej aktualny stan badań, wprowadzonych jednym zdaniem (błędy typowe również dla rodzimych użytkowników języka, spowodowane brakiem sprawności językowej lub kompetencji w zakresie operowania wiedzą i analizy danych) np.:

* Prace różnych naukowców (byly - przyp. autora) poświęcone badaniu jednostek frazeologicznych, m.in. Ajdukiewicz K., Apresjan J., Baba S, Buttler D., Chlebda W., Dziamska-Lenart G., Kania S., itp.;

*istnieje możliwość głębszego zrozumienia ich twórczości poprzez szczegółowe badanie.

b) Błędy leksykalne:

- homonimy międzyjęzykowe, wewnątrzjęzykowe, kalki semantyczne, słowotwórcze, paradygmatyczne, np.:

*metod (zamiast: metoda), *pytanie (zamiast: kwestia, zagadnienie), *akademik (zamiast: uczony); * metoda próbkowania ciagłego (zamiast: metoda ekscerpcji materiału); * meta (w znaczeniu: cel); materiat dyplomowy (zamiast: praca dyplomowa); fakultet (zamiast: wydział); *specjalność (zamiast: specjalizacja, w odniesieniu do ścieżki studiów); *na podstawie naukowej (zamiast: na podstawach naukowych); *naukowo-popularny (zamiast: popularnonaukowy); *przypuszczenie (zamiast: założenie); *przedmowa (zamiast: przesłanka, założenie); *rozglada sie problem (zamiast: podejmuje się zagadnienie); *mowny obraz świata (zamiast: językowy obraz świata), *twory (zamiast: utwory);

"podać definicje pojęcia „komicznego” we współczesnym literaturoznawstwie; (zamiast: opisać pojęcie komizmu, zdefiniować termin „komizm");

*nowościa naukowa pracy licencjackiej jest (zamiast: nowatorstwo badań przedstawionych $w$ pracy dyplomowej polega na);

*materiat dyplomowy może być wykorzystany do prowadzenia zajęć z literatury obcej XIX wieku (zamiast: praca dyplomowa);

* W pracy bada sie pytanie wykorzystania nowych technologii $w$ nauczaniu słownictwa;

* zgłębianie (zamiast: pogłębiona analiza) gatunku powieści historycznej $w$ literaturze polskiej XIX wieku;

*obeznać się z (zamiast: dokonać pogłębionej analizy) leksykalnymi i semantycznymi grupami jednostek frazeologicznych we współczesnej prasie polskojezzycznej;

*rozglada się (zamiast: analizuje się) wpływ różnych typów metodycznego wspomagania (zamiast: wsparcia metodycznego) $w$ sa- 
modzielnej pracy studentów na efektywność opanowania przez nich materiałów edukacyjnych;

*przedmiotem badania naszej pracy sa szczegóty (zamiast: osobliwości) strukturalne i semantyczne funkcjonowania jednostek frazeologicznych we współczesnej prasie polskojęzycznej;

*wielu uczonych zajmowało się tym problemem. W szczególności $M$. Woźniak przedstawił relacje B. Prusa z I. Frankiem;

*Ustalona cela (zamiast: cel badań) przewiduje rozwiazanie (zamiast: realizacje) nastęujacych zadan;;

*dziś istnieje tendencja do ponownego czytania klasyków pod katem najnowszych podejść $w$ krytyce literackiej (zamiast: $w$ perspektywie najnowszych tendencji analizy tekstów w krytyce literackiej lub: nowej recepcji twórczości w perspektywie współczesnych tendencji panujacych $w$ krytyce literackiej);

- niewłaściwe stosowanie skrótów, np. *i in. (zamiast itp.);

- zaburzenia łączliwości leksykalnej wyrazów, błędy wynikające ze złego wyboru leksemu ze słownika, niewłaściwego ekwiwalentu, np.: *nauka (zamiast: nauczanie); * ugruntować teorie (zamiast: uzasadnić teorie); * odpowiednio do założeń (zamiast: zgodnie z założeniami); *aktualność pytania (zamiast: stan badań i perspektywy badawcze jako segment wstępu pracy dyplomowej); *wyświetla problematyke (zamiast: porusza problematyke);

*Przedmiotem badania naszej pracy sa szczegóty strukturalne $i$ semantyczne funkcjonowania jednostek frazeologicznych we współczesnej prasie polskojęzycznej (zamiast: osobliwości cech strukturalnych i semantycznych lub: charakterystyka strukturalno-semantyczna);

*Swoja praca utorowat droge od publikacji literackich do epickiej powieści społecznej i opowiadania, które byli w stanie szerzej i petniej ogarnać relacje społeczne. (zamiast: opisać, ujać temat relacji społecznych);

*We wnioskach podkreślono (zamiast: przedstawiono) główne postanowienia (zamiast: tezy, ukr. положення - pol. postanowienie w języku prawniczym).

c) Błędy gramatyczne:

- w zakresie stosowania form bezosobowych, np. *było przeanalizowano (zamiast: przeanalizowano);

- błędy składni, nieznajomość spójników skorelowanych, składni liczebnika, błędy w rekcji, anakoluty składniowe, nieprawidłowe elipsy, np.:

*możliwość zbadać (zamiast: możliwość zbadania); " próba zwerbalizować (zamiast: próba zwerbalizowania, lepiej: próba opisu); *jak w języku ukrainskim, tak polskim (zamiast: zarówno..., jak i...);

*Artykut jest adresowany nauczycielom jezyka polskiego, studentom polonistyki i wszystkim zainteresowanym językiem polskim 
(zamiast: adresowany do nauczycieli, lepiej: skierowany do nauczycieli, opracowany z myśla o nauczycielach);

*Problematyka frazeologii somatycznej przez długi czas (zamiast: od długiego czasu, lepiej: od dawna) jest przedmiotem zainteresowania wielu badaczy;

*Wielu naukowców badali różne aspekty jego dorobku twórczego (zamiast: wielu naukowców badało);

*Badanie słownictwa społeczno-politycznego $w$ aspekcie leksykalno-semantycznym pozwala zidentyfikować, które obszary życia politycznego ważne dla rodzimych użytkowników języka polskiego, a które peryferyjne (zamiast: sa ważne);

*Osiagnięcie tego celu wiaże się $z$ realizacja nastepujacych zadań: 1) scharakteryzować pojeccie i typologie frazeologii; 2) zbadać ksztattowania sie frazeologii jako nauki $w$ Polsce; 3) obeznać sie leksykalnymi $i$ semantycznymi grupami jednostek frazeologicznych we współczesnej prasie polskojęzycznej; 4) dokonać analizy semantycznej frazeologizmów na łamach prasy polskojęzycznej (zamiast: scharakteryzowanie, a raczej: zdefiniowanie, opis; zbadanie, a raczej: analiza procesu formowania sie frazeologii jako nauki, analiza sposobu kształtowania sie frazeologii jako nauki);

- nadużywanie przyimka dla (zamiast: do);

- stosowanie ukraińskich modeli fleksyjnych nazwisk i nazw własnych, np. Szewczenka, zamiast: Szewczenki;

- w zakresie stosowania strony czynnej i biernej, np.: *Jednocześnie uwaga naukowców koncentruje się na kwestiach wzbogacania $i$ kształtowania słownictwa społeczno-politycznego (zamiast: jest skoncentrowana).

d) Błędy ortograficzne i interpunkcyjne, np.:

- typowe błędy ortograficzne, np.: *objektem badań;

- błędy w zakresie zapisu nazwisk, błędne lub niekonsekwentne stosowanie wzorca transkrypcji i transliteracji, stosowanie zasad transliteracji ukraińskiej w tekstach polskich (szczególnie w zakresie liter i połaczeń literowych mylone są: $l: l ; v: w ; c h: c z ; h: k h$; $h: g$; ie : je : ye; $i: j i: i i: y$; sh: sz, oddajace ukraińskie litery: $\Omega$, $\epsilon, ю, u, u$, ж, дз, $л, \check{u}, i, i)$, np.: *N.D. Babycz, M.P. Ivczenko, L.H. Skrypnyk, H.M. Udovyczenko, I.K. Bilodid, W.S. Vaszczenko, I.S. Hnatyuk, H.B. Zorivczak, W.S. Kalasznyk, A.P. Koval, I.H. Czerednyczenko $i$ inni;

*Zalecki, W. Szałkiewicz, J. Bartyzel, B. Schlachta, O.E. Sękowska, M. Sokołowski, A. Stenpinska, J. Jakubowski, D. Piontek i inni;

- dokonywanie transliteracji nazwisk nieukraińskich (polskich i obcych) naukowców i pisarzy $z$ języka ukraińskiego na język polski zamiast podawania oryginalnego brzmienia (Shakespeare) czy polskiego wariantu (Szekspir), np.: Ferdynand de Sosjur, zamiast: Ferdynand de Saussure, *Bodler (zamiast: Baudelaire), *Kocha- 
nowskyj (zamiast: Kochanowski); *J. Bartminski (zamiast: J. Bartminski);

- błędy w zakresie zapisu skrótów, np.: *i tp. (zamiast: itp.), *№ (zamiast: $n r$ );

- tendencja do używania znaku " " do oznaczania cytatów, zamiast " ", odmiennie niż w języku polskim.

e) Błędy pozajęzykowe:

- błędy merytoryczne;

- nieprzestrzeganie praw autorskich, zasad zwiazanych z prawem cytatu, plagiat.

Błędy pozajęzykowe dotyczą również rodzimych użytkowników języka, jednak skala plagiatów, $z$ która się spotkała autorka w swoim doświadczeniu dydaktycznym na Ukrainie, jest większa niż w Polsce, dlatego na ten aspekt kompetencji akademickich należy zwrócić szczególną uwagę w pracy ze studentami.

Oczywiście zdarzają się fragmenty tekstów, które trudno jednoznacznie zinterpretować ze względu na znaczny stopień zakłócenia komunikacji i nawarstwienie się błędnych konstrukcji (leksykalnych, gramatycznych i frazeologicznych, nieudane metafory, skróty myślowe itp.). Wymagaja one gruntownej korekty, niejednokrotnie ponownej redakcji, np.: *Frazeologia odgrywa znaczaca role $w$ skomplikowanym procesie ludzkiego myślenia $i$ światopogladu (zamiast: frazeologia odgrywa znaczaca role w kształtowaniu językowego obrazu świata lub: tym samym wpływa na światopoglad $i$ kulture ); *Jednostki frazeologiczne wchłonęły wydarzenia historyczne $i \dot{z} y c i e$ społeczne, opowiadaja o rozległym świecie ludzkich uczuć, wrażaja dokładnościa zwiazków między natura, zwykłymi faktami życia, ludzkim zachowaniem, naszymi emocjami i działaniami.

Pracujac nad interferencjami gramatycznymi, można wykorzystać dostępne podręczniki adresowane do osób słowiańskojęzycznych [np. Izdebska, Długosz 2021a; Кравчук 2016]. O sposobach pokonywania interferencji w nauczaniu języka polskiego osób pochodzacych z Ukrainy pisał Bartłomiej Maliszewski [Maliszewski 2019]. Niestety, dotychczas nie opracowano podręcznika $z$ myśla o błędach w zakresie struktur leksykalnych typowych dla języka nauki $z$ uwzględnieniem interferencji polsko-ukraińskich czy polsko-rosyjskich. Na pewno taki podręcznik byłby pomocny na etapie wprowadzania struktur językowych typowych dla języka polskiego $\mathrm{w}$ odmianie akademickiej. Jak widać $\mathrm{z}$ powyższego zestawienia błędów, wiele $z$ nich ma charakter kalk językowych, a u ich źródeł leży zjawisko homonimii międzyjęzykowej i wewnątrzjęzykowej. Na początek może warto opracować słownik homonimów polsko-ukraińskich w obszarze języka polskiego do celów naukowych, a w kolejnym etapie słownik języka polskiego w odmianie ogólnej akademickiej czy chociażby inwentarz leksykalny. Tymczasem warto korzystać ze wspomnianego powyżej podręcznika Iwony Kugiel-Abuhasny [Kugiel-Abuhasna 2019] czy innych opracowanych dla studentów, np. [Bajor, Madeja 2006]. 
Wprowadzanie struktur leksykalnych i gramatycznych stanowi ważny etap w procesie rozwijania sprawności recepcji i redakcji tekstów o charakterze naukowo-dydaktycznym. Biorąc pod uwagę opisane powyżej deficyty studentów, nie należy zapominać o realizacji pozostałych umiejętności zapewniających biegłość w tym zakresie. Są to:

- znajomość struktur gatunków i zwyczajów redakcyjnych,

- kształcenie kompetencji myślenia analitycznego i krytycznego,

- rozwijanie sprawności operowania danymi,

- rozwijanie umiejętności korzystania ze źródeł,

- kształcenie nawyku precyzyjnego myślenia i wyrażania myśli,

- rozwijanie umiejętności świadomego kształtowania wypowiedzi,

- wspieranie umiejętności samodzielnego uczenia się.

Ucząc języka nauki (języka wiedzy), uczymy myślenia, zdobywania, organizacji i porządkowania wiedzy - procesów, u których podstaw leży filozofia poznania. Uczymy sztuki, która spośród wielu środków ekspresji językowej pozwala wybrać te najodpowiedniejsze do wyrażenia własnych myśli i intencji przy uwzględnieniu wielu okoliczności i elementów sytuacji komunikacyjnej. Jest to zawsze sztuka wyboru, oscylujacca pomiędzy dyscyplina podyktowana precyzja komunikatu, realizacją wzorca gatunkowego, wybraną metodologia badań, perspektywą badawcza, tradycja terminologiczna $-z$ jednej strony, a wyznaczaniem nowych szlaków i tworzeniem nowych modeli, teorii i paradygmatów naukowych $-z$ drugiej strony. Jest to zatem sztuka balansowania pomiędzy domykaniem a otwieraniem. W świecie nauki, w którym przez setki lat dążyło się do poznania obiektywnej prawdy o rzeczywistości, jest miejsce na indywidualna ekspresję. Kompetencje w zakresie odbioru i redakcji tekstów naukowych wpisują się w ten model - uczą twórczej realizacji wzorca gatunkowego. Jak każda sztuka, wymagają odrobiny talentu, uwarunkowane sa więc po części potencjałem osobowościowym studenta, który należy szlifować, pamiętając, że praktyka czyni mistrza.

$\mathrm{W}$ przygotowaniu studentów $z$ Ukrainy do podjęcia studiów w języku polskim, spełniając postulaty współczesnej glottodydaktyki, należy uwzględnić zarówno zastany potencjał, jak i specyficzne potrzeby w zakresie kompetencji ogólnych i komunikacyjnych ze szczególnym uwzględnieniem obszarów interkomprehensji i interferencji językowych. Przedstawiony w artykule katalog gatunków typowych dla języka polskiego w odmianie akademickiej ogólnej, a także zestawienie błędów studentów w realizacji wzorca gatunkowego, może być podstawą dalszych prac nad rozwiązaniami praktycznymi w dydaktyce polonistycznej, jak również badań w obszarze glottodydaktyki języka polskiego do celów akademickich. 


\section{Bibliografia}

E. Bajor, E. Madeja, 2006, Wśród ludzi i spraw, Łódź.

S. Busiło, 2019, Język polski jako obcy w odmianie ogólnej akademickiej dla studentów z Ukrainy - nowe wyzwania dla glottodydaktyki polonistycznej, Międzynarodowa Konferencja Naukowa z Okazji 15-lecia Katedry Filologii Polskiej Narodowego Uniwersytetu Lwowskiego im. I. Franki pt. Polonistyka w świetle tradycji i wyzwań współczesności (tom pokonferencyjny w opracowaniu).

A. Chojecki, 1997, Mowa mowy. O języku współczesnej humanistyki, Gdańsk.

J. Pelc (red.), 2000, Język współczesnej humanistyki, Warszawa.

A. Dunin-Dudkowska, 2018, Gatunki wypowiedzi w kontekście glottodydaktycznym, „Acta Universitatis Lodziensis. Kształcenie Polonistyczne Cudzoziemców” nr 15, s. 111-122.

D. Dunin-Dudkowska, B. Maliszewski, 2018, Jak lepiej (nie) pisać? O błędach popetnianych przez Ukrainców zdajacych egzamin certyfikatowy $z$ języka polskiego jako obcego [w:] A. Krawczuk, I. Bundza (red.), Polonistyka w XXI wieku: między lokalnym a globalnym, Kijów, s. 354-363.

S. Dubisz, 2015, Językoznawcze studia polonistyczne (pisma wybrane, uzupetnione, zmienione), cz. III: Stylistyka - retoryka - translatoryka, Warszawa.

S. Gajda, 1982, Podstawy badań stylistycznych nad językiem naukowym, Warszawa-Wrocław.

S. Gajda, 1994, Styl naukowy [w:] J. Bartmiński (red.), Encyklopedia kultury polskiej XX w., t. 2: Współczesny język polski, Wrocław, s. 173-189.

S. Gajda, 1996, Kultura języka naukowego [w:] J. Miodek (red.), O zagrożeniach $i$ bogactwie polszczyzny, Wrocław, s. 213-228.

S. Gajda, 1999, Język nauk humanistycznych [w:] W. Pisarek (red.), Polszczyzna 2000, Opole.

Orędzie o stanie języka na przełomie tysiącleci, Kraków, s. 12-32.

S. Gajda, 2001a, Gatunkowe wzorce wypowiedzi [w:] J. Bartmiński (red.), Wspótczesny język polski, Lublin, s. 255-268.

S. Gajda, 2001b, Język naukowy [w:] S. Gajda (red.), Najnowsze dzieje języków słowiańskich. Język polski, Opole, s. 294-315.

G. Hofstede, G.J. Hofstede, 2007, Kultury i organizacje, Warszawa.

T. Hutchison, A. Waters, 1987, English for specific purposes, Cambridge.

K. Hyland, 2008, English Academic Purposes. An advanced resource book, Routledge-Londyn-Nowy Jork.

D. Izdebska-Długosz, 2021a, Polski dla nas. Deklinacja i składnia kontrastywnie dla Słowian wschodnich (A2-B2), Kraków.

D. Izdebska-Długosz, 2021b, Błędy gramatyczne $w$ polszczyźnie studentów ukraińskojęzycznych, Kraków.

I. Janowska, E. Lipińska, A. Rabiej, A. Seretny, P. Turek (red.), 2016, Programy nauczania języka polskiego jako obcego. Poziomy A1-C2, Kraków.

M. Jaroszewska, D. Ekiert-Oldroyd (red.), 2002, Aktywne metody nauczania $w$ szkole wyższej, Poznań.

A. Jasińska, 2019, B1 i co dalej? O konieczności przygotowania programu nauczania języka polskiego jako obcego dla celów akademickich, „Neofilolog” 53/1, s. 129-142, https://doi.org/10.14746/n.2019.53.1.9 [dostęp: 10.04.2021].

A. Jasińska, 2020, Postulaty Rady Europy jako pomoc $w$ tworzeniu programu języka polskiego dla celów akademickich w nowych realiach globalnych. Wy- 
brane propozycje glottodydaktyczne [w:] A. Piotrowicz, M. Witaszek-Samborska (red.), Kultura komunikacji w dydaktyce, Poznań, s. 103-114.

A.M. Johns, 1997, Text, role and context: developing academic literacies, Cambridge.

I. Kononenko, 2012, Studium kontrastywne języka polskiego i ukraińskiego, Warszawa.

I. Kononenko, I. Mytnik, E. Wasiak, 2010, Słownik tematyczny polsko-ukrainski, Warszawa.

J. Kowalewski, 2017, Język polski na Ukrainie w perspektywie glottodydaktycznej, Kraków.

I. Kugiel-Abuhasna, 2019, Studiologia. Podrecznik do języka naukowego dla cudzoziemców na poziomie B1, Kraków.

A. Krawczuk, 2006, Błędy gramatyczne studentów polonistyki lwowskiej powodowane polsko-ukrainska interferencja, „Postscriptum” nr 2(52), s. 137-153.

S. Krashen, 2011, Academic proficiency (language and content) and the role of strategies, TESOL Journal 2(4), s. 381-393.

P. Levchuk, 2020, Trójjęzyczność ukraińsko-rosyjsko-polska Ukraińców niepolskiego pochodzenia, Kraków.

E. Lipińska, E.G. Dąmbska, 2016, Pisać jak z nut, Kraków.

B. Maliszewski, 2019, Ku absencji interferencji-sposoby utrwalania poprawnych form gramatycznych $w$ nauczaniu języka polskiego młodzieży $z$ Ukrainy, „Roczniki Humanistyczne” t. LXVII, z. 10, Lublin, s. 99-112.

A. Ruszer, 2013, Oswoić tekst, Kraków.

A. Seretny, E. Lipińska, 2015, ABC metodyki nauczania języka polskiego jako obcego, Kraków.

J. Swales, 1995, English for Academic Purposes, Cambridge.

J. Swales, 2007, Genre Analysis: English in Academic and Research Settings (Cambridge Applied Linguistics), Cambridge.

J. Swales, C. Feak, 2012, Academic writing for graduate students, Michigan.

M. Sydor, 2014, Wskazówki dla piszacych prace dyplomowe, Poznań.

Z. Szkutnik, 2005, Metodyka pisania pracy dyplomowej: skrypt dla studentów, Poznań.

O. Śpiwak, M. Jurkowski, 2003, Ukrainsko-polski słownik syntaktyczny, Warszawa.

H. Widdowson, 1983, Learning purpose and language use, Oxford.

M. Wojtak, 2013, Tekst i jego gatunki $w$ ostatnim siedemdziesięcioleciu [w:] A. Dunin-Dudkowska, A. Małyska (red.), 70 lat współczesnej polszczyzny. Zjawiska, procesy, tendencje, Lublin, s. 85-107.

G. Zarzycka, 2017, Język polski w odmianie akademickiej. Propozycja programu kursu adresowanego do studentów zagranicznych przygotowujacych się do studiów wyższych $w$ Polsce, „Acta Universitatis Lodziensis. Kształcenie Polonistyczne Cudzoziemców" t. 24, s. 135-148.

Г.С. Онуфрієнко, 2009, Науковий стиль украӥнсъкої мови, Київ.

В.В. Каплінський, 2015, Методика викладання у вищій школі, Вінниця.

М.М. Козмова, 2014, Методика викладання у вишій школі, Одеса.

I. Кононенко, О. Співак, 2008, Українсько-польсъкий словник омонімів і паронімів, Київ.

А. Кравчук, 2011, Аексикологія і культура польської мови, t. 2, Київ. 
А. Кравчук, 2016, Польсъка мова. Граматика з вправами, Київ.

А. Кравчук, Є. Ковалевський, 2017, Методика викладання польської мови, Київ.

\section{Gatunki naukowe i dydaktyczne w edukacji polonistycznej na Ukrainie}

\section{Streszczenie}

Artykuł wpisuje się w krąg badań glottodydaktycznych z zakresu dydaktyki nauczania języka polskiego jako obcego w odmianie akademickiej ogólnej oraz lingwistycznych w obszarze stylistyki języka polskiego i genologii. Porusza zagadnienie kształcenia językowego studentów z Ukrainy podejmujacych studia w Polsce. Autorka analizuje specyfikę rozwoju kompetencji w zakresie rozumienia i tworzenia tekstów reprezentujacych gatunki naukowo-dydaktyczne w perspektywie porównawczej polsko-ukraińskiej z uwzględnieniem zjawiska interkomprehensji i interferencji językowej. Na podstawie analizy praktyk edukacyjnych w Polsce i na Ukrainie, a także tekstów prac dyplomowych studentów z Ukrainy, opierając się na własnym doświadczeniu pracy dydaktycznej, autorka przedstawia propozycję katalogu gatunków akademickich oraz błędów w redakcji tekstów naukowo-dydaktycznych typowych dla osób słowiańskojęzycznych.

Słowa kluczowe: język polski do celów akademickich - język polski w odmianie akademickiej ogólnej - kształcenie językowe studentów słowiańskojęzycznych - gatunki akademickie.

\section{Polish academic writing for Ukrainian students. Genre analysis}

\section{Summary}

The paper analyses the issue of academic writing in Polish. The author analyses the specific characteristics of the development of competences in the field of understanding and creating texts representing scientific and didactic genres from the Polish-Ukrainian comparative perspective, taking into account the phenomenon of intercomprehension and linguistic interference. Based on the analysis of educational practices in Poland and Ukraine, as well as the texts of the diploma theses of students from Ukraine, based on her own experience in teaching, the author presents a catalogue of academic genres and frequent errors in academic writing made by Ukrainian students.

Keywords: Polish for academic purposes - Polish for general academic purposes - Polish language for Ukrainian students - academic genres.

Adj. Monika Czarnecka 